\title{
Leptospirosis in Febrile Patients: Diagnosis by Serology and Polymerase Chain Reaction
}

\author{
Khalid Perwez \\ Department of Biotechnology, P. A. College of Engineering \\ VTU, Mangalore, Karnataka, India \\ Suman VB \& Nayanatara Arun Kumar \\ Department of Physiology, Kasturba Medical College, Manipal University \\ Mangalore, Karnataka, India \\ E-mail: drsumanperwez@yahoo.com \\ Mohammad Asif Hussain \\ Department of Electrical and Computer Eng, Biomedical Engineering Group \\ King Abdul Aziz University, Jeddah, Kingdom of Saudi Arabia
}

Received: December 31, 2010 Accepted: January 16, 2011 doi:10.5296/jbls.v2i1.535

\begin{abstract}
Introduction: Leptospirosis is a zoonotic disease found in all tropical and temperate areas of the world. Humans contract leptospira through mucosal or percutaneous exposure to environments contaminated by the urine of chronically infected animal sources mainly rodents, dogs, pigs and cattle.
\end{abstract}

Objectives: It is known that IgM ELISA is used widely to diagnose leptospirosis in acute stage of illness.

Our aim is to evaluate the sensitivity and specificity of a molecular technique like PCR in reference to the serological test Pan Bio, IgM ELISA, and its usefulness as a diagnostic test in the diagnosis of leptospirosis.

Methods: The patients included 85 males and 15 females, age 2yrs-78 yrs, (median age, 40yrs). Common presenting symptoms were Fever, myalgia, jaundice, nausea and vomiting, oliguria and acute renal failure. Blood samples were drawn during the acute phase of illness, 


\section{Macrothink}

7.5 mean days from the onset of symptoms. All the samples were tested for IgM antibody by ELISA and for Leptospira DNA by PCR. Detection of antibody done by Pan Bio Leptospira IgM ELISA. Detection of DNA by PCR: Extraction of DNA: was performed using the QIAGEN mini kit. Amplification of DNA: Primers used to amplify a 631 base-pair (bp) 5'-region of $16 \mathrm{~S}$ rDNA of pathogenic leptospira, Detection of DNA: by Agarose gel electrophoresis

Results: All 100 samples were tested by both ELISA and PCR. 35 samples (35\%) were positive for the presence of IgM antibodies by ELISA. PCR demonstrated DNA in 34 of the samples. A total of 28 samples were positive by both ELISA and PCR. The PCR demonstrated a sensitivity of $80 \%$ and specificity of $90 \%$.

Conclusions: PCR is a sensitive and specific technique which can detect the presence of DNA in the very early stage of the disease; Results of PCR can give us a presumptive diagnosis of leptospirosis in early phase of illness (1-7days) compared to Pan Bio IgM ELISA. Hence PCR together with IgM ELISA can be used to confirm the diagnosis, in the acute stage (1-15days) of the infection.

Keywords: Leptospirosis, IgM Antibody, ELISA, DNA, PCR 


\section{Introduction}

Leptospira can be found in virtually all tropical and temperate areas of the world and is presumed to be the most wide spread zoonosis in the world ${ }^{\mathbf{1}}$. Humans contract leptospirosis through mucosal or percutaneous exposure to leptospires in environments contaminated by the urine of chronically infected animal sources. The most common animals implicated as sources of leptospiral transmission are domestic or agricultural rodents, dogs, pigs and cattle.( Plank, R., 2000) Leptospirosis is found in a wide variety of environmental contexts, in industrialized and developing countries, and in urban and rural contexts (Everard, J. D., 1993). Leptospirosis has been consistently reported from the Andaman and Nicobar group of Islands (thus called 'Andaman Hemorrhagic Fever') West Bengal, Kerala and Coastal Karnataka (John, J.T., 1996; Roy, S., 2005).

Despite being common, the diagnosis of leptospirosis is often not made unless a patient presents with textbook manifestations of the so called Weil's disease, such as fever plus jaundice, renal failure and pulmonary hemorrhage. Leptospiral infection often has minimal or no clinical manifestations; In both children and adults, leptospirosis commonly presents with fever, myalgia, and headache. Lethargy, emesis, abdominal pain, photophobia, arthralgia, cough, diarrhea, or constipation also may occur.

Onset of symptoms often occurs abruptly after 2 to 20 days incubation period. Direct tissue injuries from leptospirae invasion and toxins, which have been theorized yet never clearly elucidated, characterize the acute phase. Symptoms then abate with cessation of the systemic proliferation of leptospires. The second or immune phase is characterized by increasing antibody titers and inflammatory infiltration of affected organ systems. Aseptic meningitis and renal dysfunction are hallmarks of the immune phase. Symptoms may persist for 6 days to more than 4 weeks, with a mean duration of 14 days.

Approximately $10 \%$ of patients diagnosed with leptospirosis develop signs of Weil's disease. The classic definition of Weil's disease is severe leptospirosis presenting with jaundice, renal failure, and pulmonary hemorrhage. Mortality rates among these patients is $10 \%$, despite care in an intensive care unit (ICU), and even higher in regions with less sophisticated care. Severe, fatal cases of leptospirosis may occur without associated jaundice. Of the cases in which fever develops, as many as $90 \%$ are undifferentiated febrile illnesses. Because of the variety of clinical symptoms seen in the symptomatic cases, leptospirosis at its onset is often misdiagnosed as aseptic meningitis, influenza, hepatic disease or fever (pyrexia) of unknown origin(Turner, 1967). In developing countries, laboratory facilities may be inadequate for diagnosis despite a high prevalence of the disease. Of substantial clinical importance, the syndrome of leptospiral pulmonary haemorrhage has emerged in recent years, in diverse places around the world.

Two important issues continue to confront clinicians regarding leptospirosis. The first is how to reliably establish the diagnosis. The most common way to diagnose leptospirosis is through serological tests either the Microscopic Agglutination Test (MAT) which detects serovar-specific antibodies, or a solid-phase assay for the detection of $\operatorname{IgM}$ antibodies. Leptospira are present in the blood until they are cleared after 4-7 days following the 
production of Leptospira-specific antibodies, initially mainly of the Immunoglobulin M (IgM) class (Chernukha, 1976; Silva, 1995). However, the greatest drawback of IgM detection assays is that $\operatorname{IgM}$ antibodies can persist for many months raising the questions about whether a positive IgM result accurately identifies a current infection(Cumberland, 2001).

The Microscopic Agglutination Test (MAT) is the cornerstone of the serodiagnosis of leptospirosis, because this assay has a high sensitivity and allows for the detection of group specific antibodies (Brandão, 1998). Two major disadvantages of this test are that in regions where leptospirosis is common, there may be a substantial proportion of the population with elevated titres of MAT and secondly, the performance of MAT is restricted to laboratories that are capable of maintaining strains for the preparation of live antigens(Turner, 1968). Therefore, serological tests remain suboptimal for clinical use in diagnosing leptospirosis. The most promising diagnostic methods are those that demonstrate the presence of the organisms.

Culture of Leptospira is difficult for a variety of reasons. The process is very laborious, and can take up to 3 months(Hookey, J. V., 1992). Therefore, isolation and culture are primarily used for retrospective diagnosis.

\section{Objectives}

To evaluate the sensitivity and specificity of a molecular technique like PCR in comparison to the serological test Pan Bio, IgM ELISA, and its usefulness as a diagnostic test in the diagnosis of leptospirosis. To detect the presence of Leptospira-specific IgM antibodies from serum in by indirect ELISA. To further detect the DNA by PCR for the pathogenic Leptospira spp.

\section{Materials and Methods}

A total of 100 serum samples received at the Central laboratory of the Clinical Microbiology Department, Kasturba Medical College, Mangalore, for investigation of leptospirosis or other febrile infections endemic in this region (e.g. Typhoid, Dengue and Malaria, ) were taken for the study. Prior approval from the Institutional Ethics Committee was obtained for the study.

The samples were collected during the months of September and October, just following the monsoon season, when the incidence of Leptospirosis is high.

Clinical history and details of the patient relevant to the study was obtained from the requisition forms and clinicians. The patients included 85 males and 15 females, age 2yrs-78 yrs, (median age, 40yrs). Common presenting symptoms were Fever, myalgia, jaundice, nausea and vomiting, oliguria and acute renal failure. Samples were drawn during the acute phase of illness, 7.5 mean days from the onset of symptoms. About $5 \mathrm{ml}$ of plain blood or EDTA blood from patients was collected. Serum was separated from the plain blood samples and both were stored at $-20^{\circ} \mathrm{C}$.

Samples which that are hemolysed or lipemic are not included

\subsection{Procedure}

All the samples were tested for IgM antibody by ELISA and for Leptospira DNA by PCR. 


\section{Macrothink}

\subsubsection{Detection of antibody by Pan Bio Leptospira IgM ELISA}

PanBio Leptospira IgM ELISA reagents were obtained from the manufacturer (Pan-Bio, Queensland, Australia). Sera to be tested were diluted 1:100 in serum diluent supplied by the manufacturer, and $100 \mu \mathrm{L}$ of the resulting dilutions were added to antigen-coated microwells. Positive and negative controls were included in each test run, together with a calibrator serum run in triplicate. Plates were incubated at $37^{\circ} \mathrm{C}$ for $30 \mathrm{~min}$ before washing with an automated plate washer. An anti-human IgM conjugate is then added followed by the substrate. The total incubation time for this assay was 1 hour, 10 minutes. Absorbance was read at $450 \mathrm{~nm} / 600 \mathrm{~nm}$.

A Pan Bio unit was calculated for each sample by dividing the absorbance of the sample by the mean absorbance of the calibrator sample replicates and multiplying by 10 . A score of $<9$ units indicated a negative result, 9-11 units an equivocal result, and $>11$ units a positive result, indicating the presence of leptospira-specific IgM antibodies.

\subsubsection{Detection of DNA by PCR}

\subsubsection{Extraction of DNA}

DNA extraction was performed using the QIAGEN blood extraction mini kit according to the manufacturer's instructions. $200 \mu \mathrm{L}$ of serum or fresh blood was used as the sample volume for extraction. Extracted DNA was stored at $-20^{\circ} \mathrm{C}$ for amplification.

\subsubsection{Amplification of DNA}

\section{Primers}

Primers used to amplify a 631 base-pair (bp) 5'-region of 16S rDNA of pathogenic leptospira (Hookey, J. V., 1992) was synthesized from Sigma Aldrich Pvt. Ltd.

\section{Procedure}

PCR reaction mixture was prepared as follows

\begin{tabular}{|c|c|c|}
\hline Reagents & $\begin{array}{c}\text { Final } \\
\text { concentration }\end{array}$ & $\begin{array}{c}\text { Volume for } \mathbf{1} \text { reaction } \\
\mathbf{( 2 5} \boldsymbol{\mu L})\end{array}$ \\
\hline 10 X PCR buffer (without $\mathrm{MgCl}_{2}$ & $1 \mathrm{X}$ & $2.5 \mu \mathrm{L}$ \\
\hline $25 \mathrm{~m} \mathrm{M} \mathrm{MgCl} 2$ & $4 \mathrm{mM}$ & $4 \mu \mathrm{L}$ \\
\hline d NTP (10mM each) & $200 \mu \mathrm{M}$ & $0.5 \mu \mathrm{L}$ \\
\hline Forward primer (5uM) & $0.5 \mu \mathrm{M}$ & $2.5 \mu \mathrm{L}$ \\
\hline Reverse primer (5uM) & $0.5 \mu \mathrm{M}$ & $2.5 \mu \mathrm{L}$ \\
\hline Taq DNA polymerase ( Fermenters) & $1.5 \mathrm{U}$ & $1.5 \mu \mathrm{L}$ \\
\hline Template DNA & $1 \mu \mathrm{g} /$ reaction & $5 \mu \mathrm{L}$ \\
\hline Double distilled water & ----- & $6.5 \mu \mathrm{L}$ \\
\hline Total volume & & $25 \mu \mathrm{L}$ \\
\hline
\end{tabular}

\section{PCR amplification conditions}

The amplification was carried out in Eppendorf Master cycler under the following conditions 


\begin{tabular}{|c|c|c|}
\hline $\begin{array}{c}\text { Step1 } \\
\text { Initial denaturation }\end{array}$ & $94^{0} \mathrm{C}$ for $5 \mathrm{~min}$ & 1 cycle \\
\hline Step 2 & $94^{\circ} \mathrm{C}$ for $1 \mathrm{~min}$ & 35 cycles \\
Denaturation & $55^{\circ} \mathrm{C}$ for $1 \mathrm{~min}$ & \\
Annealing & $72^{0} \mathrm{C}$ for $1 \mathrm{~min}$ & 1 cycle \\
Extension & $72^{\circ} \mathrm{C}$ for $10 \mathrm{~min}$ & \\
\hline Step 3 & \\
\hline
\end{tabular}

3.1.2.3 Detection of DNA

\section{Agarose gel electrophoresis}

$25 \mu 1$ of the PCR products mixed with $5 \mu \mathrm{L}$ of $6 \mathrm{X}$ gel loading buffer were loaded into each well. Molecular weight markers (Bioline hyperladder), positive and negative controls were run along with the samples

The products of PCR were separated on $1 \%$ agarose gel in TAE buffer, stained with ethidium bromide at a concentration $(0.5 \mu \mathrm{g} / \mathrm{ml})$ and run at $100 \mathrm{~V}$ for 30 minutes. The results were recorded with the Alphamager gel documentation system.

\subsection{Controls for PCR}

\section{Positive controls}

Three serovars of Leptospira interrogans, L.australis, L.pomona, maintained in EMJH medium was diluted in TE buffer, boiled for 10 minutes and used as positive controls for PCR.

\section{Negative controls}

Extracted DNA of E.coli and one tube of master mix without any added DNA were used as negative controls.

\section{Extraction controls}

Serum spiked with Leptospira cultures were used as extraction controls.

\section{Statistical Analysis}

Sensitivity and specificity tests are done which are statistical measures of the performance of a binary classification test. Sensitivity measures the proportion of actual positives which are correctly identified. Specificity measures the proportion of negatives which are correctly identified

\section{Results}

All samples were collected during the acute phase of the infection. Mean of 7.5 days from the onset of symptoms. Most patients were adult males (83\%). The clinical symptoms mainly observed among the patients diagnosed with leptospirosis, were fever $(100 \%)$, myalgia $(75 \%)$, jaundice $(70 \%)$, Nausea and vomiting $(60 \%)$, acute renal failure $(30 \%)$. 


\section{Macrothink}

Journal of Biology and Life Science ISSN 2157-6076

2011, Vol. 2, No. 1: E2

A total of 100 samples were tested by both ELISA and PCR. 35 samples (35\%) were positive for the presence of IgM antibodies. A total of 5 samples showed equivocal results after repeat testing. PCR demonstrated DNA in 34 of the samples, including the 5 samples which were equivocal by ELISA. PCR was positive for 1 sample which was negative by ELISA and, 7 samples positive by ELISA were negative by PCR. A total of 28 samples were positive by both ELISA and PCR.

Table 1. Results of the IgM Pan Bio ELISA

\begin{tabular}{|l|l|l|}
\hline POSITIVE & EQUIVOCAL & NEGATIVE \\
\hline $35 \%$ & $5 \%$ & $60 \%$ \\
$>11$ Pan Bio units & $9-11$ Pan Bio units & $<9$ Pan Bio units \\
\hline
\end{tabular}

Table 2. Results of PCR

\begin{tabular}{|l|l|}
\hline POSITIVE & NEGATIVE \\
\hline $34 \%$ & $66 \%$ \\
\hline
\end{tabular}

The PCR demonstrated a sensitivity of $80 \%$ ( 95\% CI 79\%- $80 \%)$ and specificity of $90 \%$. The positive predictive value of PCR is $82 \%$ and the negative predictive value, $93 \%$.

PCR has demonstrated higher sensitivity in those samples collected during the first week of onset of symptoms.

Table 3. Results of ELISA and PCR

\begin{tabular}{|c|c|c|c|}
\hline & \multicolumn{2}{|c|}{ ELISA } \\
\hline & & POSITIVE & NEGATIVE \\
\hline \multirow[t]{3}{*}{ PCR } & 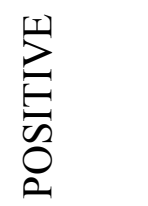 & 28 & $5+1$ \\
\hline & 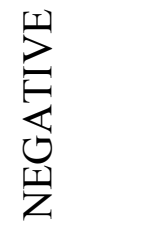 & 7 & 59 \\
\hline & TOTAL & 35 & 65 \\
\hline
\end{tabular}

Table 4. elation between the time of testing, after the onset of symptoms, and positive results of IgM ELISA and PCR

\begin{tabular}{|c|c|c|}
\hline Number of days & positive ELISA & PCR positive \\
\hline 1-7 days & 4 & 10 \\
\hline 8- 12 days & 24 & 23 \\
\hline 13-15 days & 7 & 1 \\
\hline Total number of positive samples & 35 & 34 \\
\hline
\end{tabular}




\section{Discussion}

Early diagnosis of Leptospirosis is essential in regions where Malaria, Typhoid and Dengue are also endemic. Since the specific treatment of these diseases is different, rapid and accurate diagnosis is of great significance.

Though Microscopic agglutination test is considered to be the gold standard in the diagnosis of leptospirosis, its use as a routine diagnostic test in a clinical laboratory is limited (Hookey, J. V., 1992). The test is both complex and tedious for routine use. Many studies have demonstrated Pan Bio ELISA to be more sensitive than MAT for detection of cases early in acute illness (Levett, P. N., 2001). IgM antibodies start appearing during the first week of illness though antibody levels are low or not detectable very early on in the illness. In our study leptospirosis was diagnosed in $35 \%$ of the cases on the basis of the presence of IgM antibodies by Pan Bio ELISA, in a single serum sample collected during the acute phase of the illness. In $5 \%$ of the cases the result were equivocal, a convalescent sample taken after two weeks is required to confirm the results. A limitation of using a single serum sample in the demonstration of $\operatorname{IgM}$ antibodies is the absence of antibodies very early on in the infection or the persistence of antibodies. IgM antibodies in Leptospirosis persist for a long period with varying rates of decline (Ahmed, S. N., 2005). A single serum sample taken during an acute febrile illness with symptoms of leptospirosis is presumptive evidence of infection, and therefore requires confirmation by further testing.

Our study demonstrates PCR to be more sensitive in the diagnosis of infection during the early stage of the disease. PCR confirmed the diagnosis in all the equivocal results of IgM ELISA and in 1 negative case. It failed to detect the DNA in 7 of the samples positive by ELISA, probably due to the disappearance of bacteria from the blood at that stage of the disease. Another possibility could be the use of serum samples instead of fresh blood in all these 7 cases. The bacterial concentration is less in serum than fresh blood. Studies comparing the PCR and IgM have demonstrated PCR alone to be less sensitive than serological tests over the course of the disease; it was the most sensitive method in those samples with no demonstrable antibodies collected during the very early stages of the disease (Ooteman, M.C., 2005; Fonseca de Abreu, 2006). Therefore use of PCR in combination with IgM ELISA would improve the sensitivity of the diagnosis of leptospirosis in the first phase of the disease.

\section{Limitations of the Study}

- All the samples should also be confirmed by the Gold standard, Micro Haemagglutination test (MAT).

- The sensitivity limits of PCR should be tested by spiking samples with serial dilutions of leptospira DNA.

\section{Conclusions}

When using a single sample collected during the early, acute phase of the disease, results of Pan Bio IgM ELISA can give us a presumptive diagnosis of leptospirosis. Very early on in the infection it may even fail to detect the presence of antibodies. PCR is a sensitive and specific 
technique which can detect the presence of DNA in the very early stage of the disease, so PCR together with IgM ELISA can be used to confirm the diagnosis, early on in the acute stage of the infection.

\section{References}

Ahmed, S. N., Shah, S., \& Ahmed, F.M.H. (2005). Laboratory diagnosis of leptospirosis. $J$ Postgrad Med, 51, 195-200.

Brandão, A. P., Camargo, E.D., da Silva, E.D., Silva, M.V., \& Abrão, R.V. (1998). Macroscopic agglutination test for rapid diagnosis of human leptospirosis. J Clin Microbiol, 36, 3138-3142.

Chernukha, Y. G., Shishkina, Z.S., Baryshev,P.M., \& Kokovin, I.L. (1976). The dynamics of $\mathrm{IgM}$ and $\mathrm{IgG}$ antibodies in leptospiral infection in man. Zentralbl. Bakteriol. Mikrobiol. Hyg, 236, 336-343.

Cumberland, P. C., Everard, C.O.R., Wheeler, J.G., \& Levett, P. N. (2001). Persistence of anti-leptospiral IgM, IgG and agglutinating antibodies in patients presenting with acute febrile illness in Barbados 1979-1989. Eur JEpidemiol. 17, 601-608. doi: 10.1023/A:1015509105668, http://dx.doi.org/10.1023/A:1015509105668

Everard, J. D., Everard. C.O.R. (1993). Leptospirosis in the Caribbean. Rev. Med. Microbiol, $4,114-122$.

Fonseca de Abreu, C., Teixeira de Freitas,.V.L. (2006). Polymerase chain reaction in comparison with serological tests for early diagnosis of human leptospirosis. Trop Med Inst Health, 11(11), 1699-707. doi:10.1111/j.1365-3156.2006.01727.x, http://dx.doi.org/10.1111/j.1365-3156.2006.01727.x

Hookey, J. V. (1992). Detection of Leptospiraceae by amplification of 16S ribosomal DNA. FEMS Microbiol. Lett, 90, 267-274. doi:10.1111/j.1574-6968.1992.tb05165.x, http://dx.doi.org/10.1111/j.1574-6968.1992.tb05165.x

John, J.T. (1996). Emerging and reemerging bacterial pathogens in India. Indian J Med Res, 103, 4-18.

Levett, P. N., Branch, S.L., Whittington,C.U., Edwards, C.N., and Paxton, H. (2001). Two methods for rapid serological diagnosis of acute leptospirosis. Clin. Diagn. Lab. Immunol. 8, 349-351.

Ooteman, M.C., Vago, A.R., \& Koury, M.C. (2005). Evaluation of MAT, IgM ELISA and PCR methods for the diagnosis of human leptospirosis. Journal of Microbiological Methods. 65 (2), 247-257. doi: 10.1016/j.mimet.2005.07.015, http://dx.doi.org/10.1016/j.mimet.2005.07.015

Plank, R., Dean, D. (2000). Overview of the epidemiology, microbiology, and pathogenesis of Leptospira spp. in humans. Microbes and Infection, 2, 1265-1276. doi: 10.1016/S1286-4579(00)01280-6, http://dx.doi.org/10.1016/S1286-4579(00)01280-6 


\section{Macrothink}

Journal of Biology and Life Science ISSN 2157-6076 2011, Vol. 2, No. 1: E2

Roy, S., Biswas, D., Vijayachari, P., Sugunan, A.P., \& Sehgal, S.C. (2005). A clone of Leptospira interrogans sensu stricto is the major cause of leptospirosis in the Archipelago of the Andaman \& Nicobar Islands, India. Letters in Applied Microbiology, 41, 179-185. doi:10.1111/j.1472-765X.2005.01740.x, http://dx.doi.org/10.1111/j.1472-765X.2005.01740.x

Silva, M. V., Camargo, E. D., Batista, L., Vaz, A. J., Brandoa, A.P, Nakamura, P.M., and Negrao., J. M. (1995). Behaviour of specific IgM, IgG and IgA class antibodies in human leptospirosis during the acute phase of the disease and during convalescence. J. Trop. Med. Hyg, 98, 268-272.

Turner, L. H. (1967). Leptospirosis I. Trans. R. Soc. Trop. Med. Hyg, 61, 842-855. doi:10.1016/0035-9203(67)90045-4, http://dx.doi.org/10.1016/0035-9203(67)90045-4

Turner, L. H. (1968). Leptospirosis II. Serology. Trans. R. Soc. Trop. Med.Hyg. 62, 880-889. doi:10.1016/0035-9203(68)90017-5, http://dx.doi.org/10.1016/0035-9203(68)90017-5

Winslow, W. E., Merry, D.J., Pirc,M.L., and Devine,P.L.. (1997). Evaluation of a commercial enzyme-linked immunosorbent assay for detection of immunoglobulin $\mathrm{M}$ antibody in diagnosis of human leptospiral infection. J. Clin. Microbiol. 35, 1938-1942.

Wu, W., Bao, L., Wu, Q., Li, S., \& Huang, W. (1999). Leptospirosis worldwide. World Health Organization: Wkly.Epidemiol. Rec, 647 (74), 237-242.

\section{Copyright Disclaimer}

Copyright reserved by the author(s).

This article is an open-access article distributed under the terms and conditions of the Creative Commons Attribution license (http://creativecommons.org/licenses/by/3.0/). 